\title{
The use and abuse of mathematical economics
}

Michael Hudson [Levy Economics Institute and Uni. of Missouri, K.C, USA]

Copyright: Michael Hudson, 2010

You may post comments on this paper at

http://rwer.wordpress.com/2010/12/17/rwer-issue-55-michael-hudson-math/

\begin{abstract}
- "There are more things in heaven and earth, Horatio, than are dreamt of in your philosophy." (Hamlet, Act I, scene v)
\end{abstract}

"Whoever enters here must know mathematics." That was the motto of Plato's Academy. Emphasizing the Pythagorean proportions of musical temperament and the calendrical regularities of the sun, moon and planets, classical philosophy used these key ratios of nature as an analogue for shaping order in society's basic proportions. The population's optimum size, the city's geometric shape and its division into equal "tribal" fractions for voting and fighting in the army were mathematically idealized. But there was little quantitative analysis of economic relations, and certainly no thought that unregulated market forces would assure social harmony. There was no statistical measurement of the debts that wracked the Greek and Roman economies, or of overall output, its distribution and value.

We now have such measures, but can we say that mathematics provides the key to understanding the major economic problems of our time? More specifically, has the marginalist and monetarist application of mathematics become so nearsighted as to lose sight of the economy's structural problems?

The education of modern economists consists largely of higher mathematics, which are used more in an abstract metaphysical way than one that aims at empirically measuring society's underlying trends. It is now over a century since John Shield Nicholson (1893:122) remarked that "The traditional method of English political economy was more recently attacked, or rather warped," by pushing the hypothetical or deductive side . . . to an extreme by the adoption of mathematical devices. . . . less able mathematicians have had less restraint and less insight; they have mistaken form for substance, and the expansion of a series of hypotheses for the linking together of a series of facts. This appears to me to be especially true of the mathematical theory of utility. I venture to think that a large part of it will have to be abandoned. It savors too much of the domestic hearth and the desert island.

If today's economics has become less relevant to the social problems that formed the subject matter of classical political economy a century ago, its scope has narrowed in large part because of the technocratic role played by mathematics. This paper asks whether this has been an inherent and inevitable development. Has the narrowing of scope of economics since the anti-classical reaction of the 1870 s - the so-called neoclassical revolution of William Stanley Jevons, Carl Menger, and later of Alfred Marshall and his followers, culminating in today's Chicago School - been inherent in the mathematization of economics? Or, does it follow from the particular way in which mathematics has been applied?

What is the proper role for mathematics to play? Is there such a thing as bad mathematical economics? What kinds of problems do its formulations tend to exclude? 


\section{Mathematical economics as tunnel vision}

A clue to the modern role of mathematical model-building is provided by the degree to which higher mathematics was deemed unnecessary by 18th-century moral philosophy and the political economy that emerged out of it. To be sure, the labor theory of value was formulated in quantitative terms from William Petty through Ricardo and Marx. Britain's political arithmeticians used statistics, as did the German cameralists. The quantification of magnitudes gives concrete empirical expression to one's logic. But statistical calculations of price indices or various formulae for measuring labor and capital costs are a far cry from model-building.

What has become the distinguishing feature of mathematical economics is its formulation of problems abstractly in terms of just a few selected functions, excluding all categories that cannot be expressed in its bare equations. Key dimensions of economic life have been neglected that need not logically have been omitted, such as land pricing. Despite the emphasis that Ricardo gave to rent theory, the land nationalization debate stimulated by John Stuart Mill, Herbert Spencer and Henry George, and the central role that Thorstein Veblen assigned to urban land in Absentee Ownership, land-price gains have been ignored by today's price theory. Macroeconomic analysis likewise excludes asset-price gains ("capital gains") from its definition of economic returns.

A significant role of mathematization has been to impose this narrowness on economic analysis. By focusing on how individuals spend their income on consumption goods, or defray such consumption by saving at an interest rate that allegedly reflects their "time preference" schedules, marginalist mathematics diverts the economist's eye away from the methods used to acquire and build up wealth.

The big picture - society's long-term transformation - is excluded from analysis on the ground that its dynamics cannot be sufficiently mathematized. Reiss has located the appropriate quotation from William Roscher (Grundlagen, pp. 67f.): "some scientists (attempted to) fit laws of economics in algebraic formulae ... But, of course, the advantage of the mathematical mode of expression vanishes the more, the more complex the facts to which they are applied become. . . In every description of the life of a nation the algebraic formulae would become so complicated that they render a continuation of work impossible."

To be sure, there are ways to reason mathematically with regard to national economic development, and even to changes in the economic system. Brooks and Henry Adams suggested applying the idea of phase change that had been developed by the American mathematician Willard Gibbs. ${ }^{1}$ But this suggestion fell on deaf ears. The concern of modern mathematical economists is not with social evolution and changing the status quo, but with analyzing the workings of marginal phenomena within the existing status quo.

The earliest expounders of economic relationships in terms of abstract mathematical functions were virtually ignored in their own day primarily because political economy had not yet narrowed into individualistic consumerism or technocratic business planning. It remained an extension of moral philosophy and public policy-making. The technical problems with

\footnotetext{
${ }^{1}$ Henry Adams, The Degradation of the Democratic Dogma (New York, 1919), introduction by Brooks Adams. For a discussion of the application of exponential growth to the movement of history, especially the economic applications of energy, see William H. Jordy, Henry Adams: Scientific Historian (New Haven: Yale University Press, 1953).
} 
which the early mathematical economists dealt, such as psychological utility and price formation based on supply and demand, were still far from being deemed to be the highest concern. The marginalists would make a true breakaway by viewing the consumer rather than the producer/employer as the focal point of the economic system, and discussing the economy more from the vantage point of individual psychology than from that of national industrial and financial transformation.

The early mathematical economists concerned themselves with narrower topics such as price formation, business cost accounting and railroad planning. Gossen's mathematical formulation of utility theory was not widely noticed precisely because he focused on problems hitherto considered too mundane to be deemed an essential part of political economy's core. Likewise, von Mangoldt's editor Kleinwaechter disparaged his mathematical illustration of the principles of price formation as "redundant ballast" in view of the fact that no statistical quantification was applicable. He expunged von Mangoldt's graphic examples altogether.

As for Wilhelm Launhardt's railway economics, it was considered too technical to be classified as political economy proper. His analysis did not deal with how railroads reduced transport costs, thereby benefiting the locational value of farmland, residential and commercial property along the trackway, making fortunes for real estate speculators. As any urban planner knows, this "external" effect of railways on land prices is so large as to overwhelm the narrow direct economies involved.

Early applications of mathematical notation and graphs to economic problems thus were ignored largely because they were deemed to be more in the character of engineering or merely technical business analysis than full-fledged political economy. The most essential concerns of political economy and German Nationaloekonomie were not amenable to streamlining in mathematical form. And indeed, while today's mathematical economics serves technocrats and financial strategists, it imposes a nearsighted perspective that distracts attention from what formerly was most important, in order to focus on what is merely marginal. In this sense economics has been overly distilled into the microeconomics of price theory, along with a rough macroeconomic income and output statement.

This is not to say that the building blocks of classical political economy could not be expressed quantitatively. The concept of rent served as a measure of unearned revenue by defining it as the excess of price over cost-value. Diminishing returns (or for the American protectionists, increasing returns) could be formulated mathematically, as could the productivity advantages of high-wage labor. What could not be treated with the mathematics then at hand was the political resolution of long-term structural strains. No chaos theory yet existed to deal with broad quantum leaps that occurred as political and institutional changes were introduced from outside the economic system. And as far as the dynamics of history were concerned, no mathematical formula could express the broad range of complexities that literary exposition could provide.

What made political economy the queen of the social sciences in the 19th century was its focus on the transformation of nations. It dealt with the policies most appropriate for their long-term social evolution - their legal and institutional structure, technology and financial organization. At issue was how economic institutions should be improved. The ceteris paribus methodology of marginalism did not deal with such broad contextual issues. It presupposed that the social structure remained constant, and then implied that no change was needed, as economies would respond to disturbances automatically by settling at a new 
equilibrium. Such an approach does not have much appeal to social reformers, environmentalists, political regulators or historians dealing with the structural aspects of economic development.

Marxism emerged as the preeminent alternative to the emerging marginalist economics largely because it was almost the sole survivor of classical political economy. In addition to retaining the classical breadth of scope and the idea of stages of development, Marx used irony and the idea of inner contradictions as a logical method of interpreting economic history. This was not a method that could well be expressed mathematically. Although Marx used arithmetic examples to illustrate the rates of profit and surplus value for enterprises employing differing proportions of labor and capital, this was not a mathematical model of the economy. The Communist Manifesto hardly could be expressed in mathematical formulae, and no Marxist tried to express dialectical materialism mathematically.

It has taken a hundred years to drive out what formed the most vital concerns of classical political economy: the shape of social evolution, the strains it tends to develop and the indicated responses by the state. As long as these concerns remained paramount, there would be little reason to celebrate the first users of mathematical functions as having made a great breakthrough. Their "discovery" would have to await the time in which economics narrowed its scope and dropped its concerns with long-term transformation.

The role of political economy in the 19th century was precisely to indicate the most appropriate policies for self-direction. That is what made it political economy. But as economics became increasingly technocratic, it dropped the political dimension. And as it has narrowed and come to take the institutional and political environment for granted, the mathematical formulation of economic functions has come to be used as the criterion for acceptable theorizing. The role of mathematics in fact has been to exclude problems that are more than marginal. A basic condition for regression analysis to be applied, for instance, is a constant social and political environment.

In this way mathematical economics has become the ultimate vehicle to make the policy trivialization of economics politically acceptable, establishing status quo economics as a pseudo-science by virtue of using mathematical symbolism. As Wolfgang Drechsler has quipped, mathematics has helped enthrone irrelevance as methodology. The key aspect of the mathematization of economics has been its logical necessity of stripping away what the new economic orthodoxy sought to exclude from the classical curriculum: the socially sensitive study of wealth, how it is acquired, and how its distribution (indeed, its polarization) affects social development.

\section{The semantics of mathematical equilibrium theory}

If mathematics is deemed to be the new language of economics, it is a language with a thought structure whose semantics, syntax and vocabulary shape its user's perceptions. There are many ways in which to think, and many forms in which mathematical ideas may be expressed. Equilibrium theory, for example, may specify the conditions in which an economy's public and private-sector debts may be paid. But what happens when not all these debts can be paid? Formulating economic problems in the language of linear programming has the advantage of enabling one to reason in terms of linear inequality, e.g., to think of the economy's debt overhead as being greater than, equal to, or less than its capacity to pay. 
An array of mathematical modes of expression thus is available to the economist. Equilibrium-based entropy theory views the economy as a thermodynamic system characterized by what systems analysts call negative feedback. Chaos theories are able to cope with the phenomena of increasing returns and compound interest, which are best analyzed in terms of positive feedback and intersecting trends. Points of intersection imply that something has to give and the solution must come politically from outside the economic system as such.

What determines which kind of mathematical language will be used? At first glance it may seem that if much of today's mathematical economics has become irrelevant, it is because of a fairly innocent reason: it has become a kind of art for art's sake, prone to selfindulgent game theory. But almost every economic game serves to support an economic policy.

Broadly speaking, policies fall into two categories: laissez faire or interventionist public regulation. Each set of advocates has its own preferred mode of mathematical treatment, choosing the approach that best bolsters their own conclusions. In this respect one can say that mathematics has become part of the public relations apparatus of policy-makers.

The mathematics of socialism, public regulation and protectionism view the institutional environment as a variable rather than as a given. Active state policy is justified to cope with the inherent instability and economic polarization associated with unregulated trade and financial markets. By contrast, opponents of regulation select a type of equilibrium mathematics that take the institutional environment for granted and exclude chronic instability systems from the definition of economic science, on the ground that they do not have a singular mathematical solution. Only marginal problems are held to be amenable to scientific treatment, not quandaries or other situations calling for major state intervention.

Marginalist mathematics imply that economic problems may be solved merely by small shifts in a rather narrow set of variables. This approach uses the mathematics of entropy and general equilibrium theory to foster the impression, for instance, that any economy can pay almost all its debts, simply by diverting more income from debtors to creditors. This is depicted as being possible without limit. Insolvency appears as an anomaly, not as an inevitability as in exponential growth models.

Looking over the countries in which such theorizing has been applied, one cannot help seeing that the first concern is one of political philosophy, namely, to demonstrate that the economy does not require public regulation to intervene from outside the economic system. This monetarist theory has guided Russian economic reform (and its quick bankruptcy) under Yeltsin and his oligarchy, as well as Chile's privatization (and early bankruptcy) under Gen. Pinochet, and the austerity programs (and subsequent bankruptcies and national resource selloffs) imposed by the IMF on third world debtor countries. Yet the reason for such failures is not reflected in the models. Empirically speaking, monetarist theory has become part of the economic problem, not part of the solution.

\section{The subjectivity of statistical categories}

Political economy developed out of a different tradition from statistics. The word "statistics" itself derives from "state," and early statistics accordingly dealt with public finances, debt and the economy's tax-paying capacity. The focus was on the ruler's fiscal ability to tax 
the economy and to finance deficits (mainly in times of war) through public debt. From this primary concern rulers developed an interested in how to make their economies richer, so that they could generate more public revenue. This study was called Political Arithmetic. To the extent that laissez faire policies were advocated, it was as an economic plan to encourage economic growth and hence to enhance the ruler's power to tax.

Classical political economy developed largely out of the anti-royalist political ideology of the French Physiocrats and Adam Smith opposing government regulations and taxation. The emerging individualistic discipline came to define the statistical categories that shaped peoples' quantitative perception of economic phenomena.

Accounting formats require a theoretical conceptual apparatus. Categories must be defined before actual statistics can be collected. Any set of categories is itself a conceptual structure of the parts that make up the overall picture. Empirical statistics thus reflect theoretical accounting categories, for better or worse. To mathematize economic models using obsolete or dysfunctional concepts hardly can be said to be scientific, if we define science as the understanding of how the world actually works.

It is difficult to see where economies are generating wealth without dividing their activities into the classical categories of productive vs. unproductive, i.e., wealth-creating labor vs. economic overhead. Unfortunately, few economists remember the great debate over this issue that lasted for over a century.

A case in point is the GNP accounting format developed by Simon Kuznets. Its elements are neither inherent nor entirely objective. All activities are held to be productive, rather than some (such as crime prevention, medical treatment, environmental cleanup costs and warfare) being in the character of economic overhead. The production and sale of cigarettes is counted as output, and the medical treatment of smokers as yet more national product. Crime prevention is counted, but criminal earnings are not reflected in the national income statistics.

On the other hand, the national income and product accounts do not reflect the major way in which the largest sectors - real estate, mining, fuels, forestry, and even banking and finance - take their economic returns, namely, as capital gains. These sectors appear to be operating without earning any taxable profit, and their capital gains are not traced. The accumulation of real estate fortunes and stock-market gains have become the way in which wealthy people, and money managers and homeowners have built up their wealth. But this distinguishing financial phenomenon of the present decade - asset-price inflation - is lost from view by formats that treat capital gains as "external" to their model of how the economy works.

Today's national-income concept of saving gives the appearance that at the end of 1998 the domestic U.S. saving rate was a negative 2 percent of national income. Yet savings are being built up at an unprecedented rate. The low statistical rate of savings simply reflects the high degree to which new savings find their counterpart in debt (including loans to real estate and stock market speculators seeking the afore-mentioned capital gains), rather than being invested directly in the form of new tangible capital..

Meanwhile, a rising proportion of liquid savings is coming from the world's criminals and kleptocrats. Yet national income statistics neglect the economic role played by crime, 
fraud and other illegal activities, despite their important economic role in generating many of society's major new fortunes. Only what is socially approved seems to be counted among society's shaping dynamics. (In the 1930s, when Roy Ovid Hall tried to include smuggling and other illicit activities in his balance of payments reports for the U.S. Department of Commerce, he was told sanctimoniously to desist from such behavior.)

What is not seen probably will not be taxed. In the United States, real estate and financial interests have actively discouraged collection of meaningful statistics on land-price gains. Congressmen and government bureaucrats have sought to rationalize the real estate gains of their major constituents and campaign contributors. Today's official statistics attribute so much of the price rise to the inflation of construction costs that in 1994 the value of all corporately-owned land in the United States was a negative $\$ 4$ billion! (The actual land value of U.S. real estate was over $\$ 9$ trillion at the time.)

These seemingly objective official statistics only distract attention from the reasons why so large a proportion of the economy's savings is being diverted away from new direct investment into real estate and stock market speculation. The party that suffers most is the government tax collector (and of course, labor, onto whose shoulders the tax burden is being shifted). In this respect, the aim of statistics has been inverted from their original function of informing the state how much can be taxed, to concealing taxable gains from users of modern national income statistics.

\section{Problems, dilemmas and quandaries}

Students are taught that economics is about making choices between scarce resources, but when resources really become scarce, economists tend to call it a crisis. Every such problem is stated in such a way as to imply a ready solution. Only marginal problems are recognized, not real dilemmas or quandaries. The idea of "scarcity" is just a "little bit" of scarcity - nothing that a slightly higher price won't cure (for output) or a bit lower wage (for employment problems).

Most economic models postulate that unemployment, for instance, can be solved by appropriate adjustments. "Trickle-down" theories of prosperity accordingly call for reductions in wage levels, while Keynesian theories call for or increased public spending to spur demand. Both approaches view savings as financing investment, which is assumed to take the form of tangible capital formation rather than a stock market or real estate bubble.

The important thing is that no structural problems are recognized, that is, no problems that cannot be solved by marginal quantitative adjustments in incomes, prices and wage levels, the money supply and the interest rate. It is in this respect that the mathematics of laissez faire monetarism are microeconomic, depicting the economy narrowly rather than broadly through the long-distance lens of historical development. The analysis may be valid as far as it goes, but it doesn't go very far, as it formulates problems marginally rather than with an eye for structural reform. Looking for small adjustments, such economics misses the degree to which the economy is losing its flexibility and is structurally rigidifying.

For public relations purposes, policy advocates present their "solutions" in a way that appears to make everyone better off. At least somebody's income is depicted as gaining, as if this automatically makes each inhabitant better off for living in a richer society (richer for 
whom?). Every solution seems to be a free lunch for the economy at large. What are not recognized are situations in which economies collapse because critical break-even conditions cannot be met. When this occurs, economies face dilemmas or, even worse, quandaries.

A dilemma is a situation in which whatever path or "horn" one chooses, it involves pain and the sacrifice of well-being. Somebody or some social value must lose out. Obstacles present themselves on every side, and if the economy avoids being impaled on one horn, it will fall on the other.

It should be noted that falling on one's face is a state of equilibrium. Death is indeed the ultimate state of equilibrium. So is national austerity and its transfer of property from debtors to creditors, and from domestic governments to foreign institutional investors. But marginalist and monetarist equilibrium economics employ a mathematics that does not recognize the possibility of serious dilemmas developing, or of economies falling into quandaries whose financial and economic constraints prevent technological "real" potential from being realized. The preferred method of mathematical economics is general equilibrium analysis in an environment in which only small marginal disturbances are envisioned, not major structural problems or legal changes in the economic environment.

Economies fall into a quandary when the preconditions for a real solution are lacking. Debtors default on their payments, real estate prices fall, and asset prices for bonds and stocks also fall. Banks are unable to cover their deposit liabilities as the market value of their loan portfolios falls. The government is called on to bail them out by issuing bonds, and to pay the interest charges either by raising taxes or cutting back spending programs. The budget is balanced by selling public enterprises to foreign investors, whose remission of profits and dividends creates a balance-of-payments exchange drain that lowers the currency's exchange rate.

The situation becomes worse as the government borrows from the IMF and is forced to enact an anti-Keynesian austerity program. IMF riots break out, the government falls and a dictatorship oriented to serve global financial institutions is installed, friendly to the capital flight which strips the economy of its resources all the faster. Money-capital flees abroad and skilled labor emigrates as the economy shrinks, with no technological cause indicated in the policy models being applied.

Marginal analysis avoids dealing with such quandaries, and the quantum leaps necessary to escape. It selects a rather narrow set of phenomena (labor and materials costs, the interest rate, income and the pattern of demand) to produce models that show how economies might settle at an equilibrium point if left free from outside political interference. What is missed is the degree to which the world economy is being pushed further and further out of balance.

\section{Mathematical economics as a distraction from economic reality}

Is it sufficient atonement that so many economists upon retirement merely give an apology acknowledging that, yes, perhaps their economics have all really been just a waste of time? Upon leaving office, each new president of the American Economic Association gives the expected speech showing that he knows full well it is all just a game, and chastises his colleagues for not being more realistic. But do they not have some obligation to set things right? Or is the problem that they cannot see what has to be done? 
Although academic economists hardly have shown themselves to be in favor of free markets in their own life, seeking the insulation of tenured positions and sinecures, they know well where their own money comes from. It comes from their ability to endorse creditororiented "free-market" policies and condemn government regulation. This premise has led their mathematical models to focus on how individuals can make money in our pecuniary society, but not how public entities can be better run.

The more libertarian the theory, the more authoritarian the economic pedagogy tends to be, precisely because its reasoning rests on specious foundations. In Pinochet's Chile, Chicago economists showed their intellectual intolerance of a free market in economic ideas by closing the economics and social science departments of all universities save for the Catholic University in which they ruled unchallenged. Consensus was established not through reason, but by removing from the scene all who disagreed with their extremist policies.

Over the past generation, courses in mathematical economics have displaced the traditional courses in economic history and the history of economic thought that might have familiarized students with alternatives to today's monetarist orthodoxy. Equilibrium theorizing has expunged a broad understanding of how economies work, and even the long dynamics of economic history, especially where the dynamics of debt are concerned.

The failure of mathematical economics to analyze our epoch's financial strains suggests that its aim has not really been to explain the world as much as to censor perceptions that imply that the financial status quo is unstable and hence must be regulated. Such findings are not congenial to monetarists in their capacity as the political lobby for the financial sector. By ignoring the problems caused by the growing debt overhead, monetarist orthodoxy has removed economic planning from the democratic political process and placed it in the hands of financial technocrats. The effect has been to create a new (and highly centralized) elitist planning in the world's finance ministries and central banks.

This poses the question of whether the most important phenomena and dynamics are being mathematized. Do today's general equilibrium, monetarist and national income and product models correlate the appropriate phenomena, or do they omit key dynamics?

To contemporary economists, mathematics has become the badge of scientific method. But is the use of mathematics scientific ipso facto? To what extent may it be methodologically abused?

Many economists are trained in calculus and higher mathematics without feeling much need to test their theories quantitatively. They tend to use mathematics less as an empirical measuring tool than as an expository language, or simply as a decoration to give a seemingly scientific veneer to their policy prescriptions. Mathematics rarely is used to analyze statistically the financial tendencies working to polarize wealth and income, or how economies change their shape as they grow.

This shape is distorted by the inherent tendency for financial claims - bonds, bank loans and other financial securities - to grow more rapidly than the economy's ability to carry them, much less to pay them off. The volume of such claims tends to grow by purely mathematical principles of self-expansion independently from underlying economic trends in wealth and income, and hence from the ability of debtors to pay. Savers/creditors load 
tangible capital assets and real estate down with debts that in many cases are not repayable except by transferring ownership to creditors. This transfer changes the economy's structural and, in due course, political shape.

But today's monetarist models foster an illusion that economies can carry any given volume of debt without having to change their structure, e.g., their pattern of wealth ownership. Self-equilibrating shifts in incomes and prices are assumed to enable a debt overhead of any given size to be paid. This approach reduces the debt problem to one of the degree to which taxes must be raised to carry the national debt, and to which businesses and consumers must cut back their investment and consumption to service their own debts and to pay these taxes. The task of economic regulation is reduced to one merely of setting an appropriate interest rate to reflect profit rates and consumer time-preference patterns. An array of measures is selected from the overall credit supply (or what is the same thing, debt securities) to represent "money," which then is correlated with changes in goods and service prices, but not with prices for capital assets - bonds, stocks and real estate.

Such economic models all but ignore rent-seeking exploitation and the proverbial free lunch, yet real-world economics is all about obtaining a free lunch. That is why one seeks to become a political insider, after all. Yet such considerations are deemed to transcend the narrow boundaries of economics. These boundaries seem to have been narrowed precisely so as to limit the recognized "problems" only that limited part of economic life that can be mathematized, and indeed, mathematized without involving any changes in the social environment.

The resulting logical constructs of modern mathematical economics were not created without some degree of protest. Already a generation ago F. J. Dyson (1964:132f.) complained that "Mathematical intuition is more often conservative than revolutionary, more often hampering than liberating." Citing Ernst Mach's observation that "The power of mathematics rests on its evasion of all unnecessary thought and on its wonderful saving of mental operations," he worried that too much real-world complexity might be discarded.

Certainly the mathematical "badge of science" has distracted attention from the tendency for economies to veer out of balance. ${ }^{2}$ The problem is that to achieve a single determinate, stable solution to any given problem (always posed as a "disturbance" to a preexisting balance), general equilibrium theorists are driven to assume diminishing returns and diminishing marginal utility in order to "close the system." Such an approach is not a passive tool in the sense of an X-ray machine revealing the essential skeleton of reality. It is more a distorting mirror, in the sense that it formulates problems in a way that makes them appear amenable to being solved with a single determinate solution.

This singular solution is achieved by postulating a production function based on falling productivity as more labor is applied to capital and land. As for consumption, each added unit is assumed to give less and less satisfaction, so that more revenue is saved as economies become wealthier. This means a falling marginal utility of income: The more one earns, the less one feels a need to earn more. This is fortunate, because most models also assume diminishing returns to capital, which is assumed to be invested at falling profit rates as unemployment declines. Income and wealth thus are portrayed as tapering off, not as soaring and polarizing until a financial collapse point, ecological limit or other kind of crisis is

\footnotetext{
${ }^{2}$ I discuss this problem in Trade, Development and Foreign Debt: A History of Theories of Convergence and Polarization in the World Economy (London: Pluto Press, 2 vols., 1993).
} 
reached. (It should be noted that the above variables all but ignore the economy's growing debt overhead relative to its assets, and the associated flow of interest.)

A particular kind of mathematical methodology thus has come to determine what is selected for study, recognizing only problems that have a single determinate mathematical solution reached by or what systems analysts call negative feedback. By contrast, a positive feedback model would depict an economic polarization that has an indeterminate number of possible resolutions as conflicting trends will intersect, forcing something to give. At such points the economic problem becomes essentially political. This is how the real world operates, but to analyze it would drive economists into an unstable universe in which the future is up for grabs. Such a body of study is deemed unscientific (or at least, uneconomic) precisely because it cannot be mathematized without becoming political.

\section{The hypothetical "parallel universe" approach to economics}

Marx (Capital, I:14) defined political economy's task as being "to lay bare the economic laws of motion of modern society." By contrast, equilibrium theory describes how market relations might settle at a stable resting point if only the world were something other than it is. An economic universe is envisioned that is not in political motion and that is not polarizing. This hypothetical world is characterized by automatic self-adjusting mechanisms, so that active government policies appear unnecessary. It is a world free of the financial dynamics of debt growing at compound rates of interest.

One must suspect a political reason for the aversion felt by economic model-builders to the real world's financial dynamics. To acknowledge their tendency to create structural problems would imply just what it did in Sumerian and Babylonian times: The desired economic balance must be restored by fiat, that is, from outside the economic system. Neglect of the debt overhead therefore is a prerequisite for economic models to generate laissez faire conclusions. A "what if" universe is postulated - the kind of world that might exist if finance capital were not a problem. After all, what is not quantified is less likely to be perceived and regulated.

Economies are supposed to be able to pay their debts simply by saving more. The working assumption is that saving is invested productively, not in creating yet new debts. Sufficient saving and investment thus are assumed to enable any society's growth in debt to proceed ad infinitum, as creditors are assumed to invest their earnings to further expand output and raise living standards. Any increase in saving is deemed to be good, regardless of whether it is invested productively or parasitically, physically or financially. Yet such saving in reality consists not only of direct investment in tangible capital formation. It also takes the form of stock market investment and real estate speculation in the ownership of assets already in existence, merely bidding up their price.

What is neglected is today's most characteristic pattern of lending: the investment of savings in the form of financial claims on wealth - bonds, mortgages and bank loans. Channeling savings in this way enlarges the volume of financial claims attached to existing productive assets in an exponentially expanding process. This debt overhead extracts interest charges which are recycled into yet new loans rather than financing new means of production to help economies "grow their way out of debt." 
In recent decades such debt claims have grown more rapidly than tangible investment in factories and farms, buildings and homes, transport and power facilities, communications and other infrastructure. Economies have been obliged to pay their debts by cutting back new research, development and new physical reinvestment. This is the essence of IMF austerity plans, in which the currency is "stabilized" by further international borrowing on terms that destabilize the economy at large.

Cutbacks in long-term investment also are the product of corporate raids financed by high-interest junk bonds. The debts created by businesses, consumers and national economies cutting back their long-term direct investment leaves these entities even less able to carry their mounting debt burden. They are forced to live even more in the short run. Interest rates rise as debt-strapped economies become riskier, for as Adam Smith observed, "interest rates usually are highest in countries going fastest to ruin." And as interest rates rise, yet more money is shifted away from direct investment into lending at interest, until the system is torn apart from within. Capital flees abroad, the currency falls and unemployment rises.

No doubt a point must come at which the burden grows so large that it shakes the public out of its hope that matters somehow will return to normal. In the end the global economy must be obliged to do what Adam Smith said every debtor government historically was obliged to do: let its debts go. Now that global debts are becoming dollarized, however, it is less possible for a national economies simply to inflate their way out of debt so as to make what Smith called a "pretended payment." The only options are default or outright repudiation. But it has become academic fashion to imagine alternative "virtual realities" in which no such debt problems exist.

This turns economics into something akin to science fiction. The literary critic Colin Wilson has observed that in evaluating such fiction, the proper question to be asked is, what if the world were really like this? What does such speculation teach us?

Let us ask that question of today's monetarist fantasies. Fearing government regulation to be corrosive, monetarism warns that governments should not act to shape the economic environment. In particular they should not seek to regulate financial markets, for that would kill the goose that lays the golden eggs.

But is this Planet Earth, or a hypothetical world in which the charging of interest either was never invented, or was banned long ago? Such theorizing may be useful as an exercise in "alternative history" as it might have evolved in some parallel universe. But monetarist mathematics are not those of earthly reality. The economist's idea of science itself appears otherworldly. Not being amenable to a singular determinate mathematical solution, the problem of analyzing the incompatibility between the growth in debt claims and the economy's ability to pay is deemed unscientific. In this respect the way in which modern economists use mathematics diverges from what a scientific empirical economics would be.

The main criterion for success in modern economics is its ability to maintain internal consistency in the assumptions being made. As in science fiction, the trick is to convince readers to suspend their disbelief in these assumptions. The audience is asked to take seriously problems posed in terms of a universe in which money is spent on the production of current goods and services or saved, but not lent out to create a debt problem. Students are asked to believe that debts will not tend to grow beyond the means to pay, and that any 
disturbance in the economic balance will be met by automatic stabilizing responses rather than requiring action from outside the market economy. In sum, to believe that the growth in debt overhead is not a serious problem, it is necessary to suspend our natural disbelief in the fiction that shifting the money supply can steer interest rates to a precise level that will keep the economy's debt and credit, new saving and direct investment in balance.

\section{Economics vs. the Natural Sciences: The methodology of "as if"}

What is even more remarkable is the idea that economic assumptions need not have any relationship to reality at all. This attitude is largely responsible for having turned economics into a mock-science, and explains its rather odd use of mathematics. Typical of the modern attitude is the textbook Microeconomics (1964:5) by William Vickery, long-time chairman of Columbia University's economics department, 1992-93 president of the American Economic Association and winner of the 1997 Nobel Economics Prize. Prof. Vickery informs his students that "pure theory" need be nothing more than a string of tautologies:

Economic theory proper, indeed, is nothing more than a system of logical relations between certain sets of assumptions and the conclusions derived from them. The propositions of economic theory are derived by logical reasoning from these assumptions in exactly the same way as the theorems of geometry are derived from the axioms upon which the system is built.

The validity of a theory proper does not depend on the correspondence or lack of it between the assumptions of the theory or its conclusions and observations in the real world. A theory as an internally consistent system is valid if the conclusions follow logically from its premises, and the fact that neither the premises nor the conclusions correspond to reality may show that the theory is not very useful, but does not invalidate it. In any pure theory, all propositions are essentially tautological, in the sense that the results are implicit in the assumptions made. [Italics added.]

This disdain for empirical validity is not found in the physical sciences. Ptolemaic astronomers were able to mathematize models of a solar system revolving around the earth rather than the sun. The phlogiston theory of combustion was logical and even internally consistent, as is astrology, former queen of the medieval sciences. But these theories no longer are taught, because they were seen to be built on erroneous assumptions. Why strive to be logically consistent if one's working hypotheses and axioms are misleading in the first place?

Lacking empirical testing and measurement, economics narrows into a mock-science of abstract assumptions without much regard as to whether its axioms are historically grounded. The self-congratulatory language used by economists euphemizes the resulting contrast between economics and science. "Pure" theorists are depicted as drawing "heroic" generalities, that is, banal simplicities presented in a mathematical mode called "elegant" rather than simply air-headed. To the extent that the discipline uses mathematics, the spirit is closer to numerology than to the natural sciences. Indeed, astrology also is highly technical and mathematical, and like economics it deals with forecasting. But its respectability has not lasted. Is this to be the destiny of today's economic orthodoxy? 
At first glance the sophistical tendency would appear to find an antecedent in John Stuart Mill's 1844 essay "On the Definition of Political Economy; and on the Method of Investigation Proper to it":

In the definition which we have attempted to frame of the science of Political Economy, we have characterized it as essentially an abstract science, and its method as the method a priori. . . . Political Economy, therefore, reasons from assumed premises - from premises which might be totally without foundation in fact, and which are not pretended to be universally in accordance with it. The conclusions of Political Economy, consequently, like those of geometry, are only true, as the common phrase is, in the abstract; that is, they are only true under certain suppositions, in which none but general causes - causes common to the whole class of cases under consideration - are taken into account.

Mill's objective here was to isolate the principles appropriate to each dimension of social science, so as to avoid the confusion that resulted from intermixing them. Recognizing that people and societies were multidimensional, his logical method sought to segregate the various dimensions of social existence layer by layer, so as to deal separately with the economic pursuit of wealth, the political policy arena, and the respective subject matters of the other social sciences then emerging. This was not logic for its own sake, but for the sake of a systematic analysis proceeding step by step.

However, post-classical equilibrium economists have pursued logical consistency as an objective in itself. Disembodied from reference to how the real world operates, logic has been turned into a game. Rather than forecasting how the world will respond to the strains now building up, economists project existing trends in a political and social environment that is assumed to be unchanging. When this becomes a condition of the mathematical analysis itself, the idea of economics merely as "logical consistency" plays a much less logical role than it did in Mill's day.

The problems inherent in this approach are typified by Nobel Prizewinner Paul Samuelson's conclusion of his famous article on "The Gains from Trade" (1939:205 [1966 II: 782]): "In pointing out the consequences of a set of abstract assumptions, one need not be committed unduly as to the relation between reality and these assumptions." This attitude did not deter him from drawing policy conclusions affecting the material world in which real people live. He defended his Factor-Price Equalization Theorem (which states that under a regime of free trade, wages and profits will tend to equalize throughout the global economy) by claiming (1949:182) simply that:

Our problem is . . . a purely logical one. Is 'If $H$, then inevitably $C$ ' a correct statement? The issue is not whether $C$ (factor-price equalization) will actually hold; nor even whether $\mathrm{H}$ (the hypothesis) is a valid empirical generalization. It is whether $\mathrm{C}$ can fail to be true when $\mathrm{H}$ is assumed to be true. Being a logical question, it admits of only one answer, either the theorem is true or false.

Contrasting this theorem with the real-world tendency of international incomes and wages to polarize rather than equalize, Gerald Meier (1968:227) observes: "It need not . . . come with any surprise that factor returns have been so different . . . when in short, the restrictive conditions of the theorem have been so clearly violated in reality." But is it not sophistical to speak of reality violating a theory? Theory violates reality, not the other way around. 
If one must be logical, why not start with realistic rather than merely hypothetical assumptions? The answer, I am afraid, is that realistic assumptions do not lead to the policy conclusions pre-selected by economic ideologues. This would explain why Samuelson-type trade theories continue to treat the international economy as a thermodynamic system to be analyzed by entropy theory, whereas the real-life world economy is an expanding system in which labor migrates and capital flows from low-income "cold" economies to high-income "hot" ones.

Wrong-headedness rarely is accidental; there usually is a self-interested policy motive. In his essay on "How Scientific are the Social Sciences?" Gunnar Myrdal (1956:336) observes: "Facts do not organize themselves into systematic knowledge, except from a point of view. This point of view amounts to a theory." He emphasizes that "contrary to widely held opinions, not only the practical conclusions form a scientific analysis, but this analysis itself depends necessarily on value premises."

What modern economics lacks is an epistemological dimension, the capacity for selfreflection so as to perceive the extent to which economic theorizing tends to be shaped by narrow self-interest. There is a bankers'-eye view of the world, as well as the perspective of financial manipulators, industrialists and so forth. It was the strength of Marxism to deal with economic theorizing critically on this level. Perceiving class biases, Marx viewed economic theory critically as apologetics for advocates of one policy or the other, a rhetorical system pleading for special interests. The 19th-century American protectionists likewise pointed to international biases between lead nations and latecomers regarding free trade theorizing. Today, a self-centered monetarist world view serves the global financial interests that have emerged to dominate the "real" economy. To understand its blind spots, an awareness of the self-serving motivations underlying Chicago School monetarism is necessary.

We are entitled to ask whose interests are served when economists claim that their assumptions need have no connection with reality, yet then proceed to make policy recommendations. Why do so many economics departments teach the assumptions of, say, the Heckscher-Ohlin-Samuelson theory of international equilibrium rather than starting from more realistic assumptions capable of explaining the real world's financial and economic polarization?

The products of low-wage economies exchange for those of better-paid labor for a number of reasons. Productivity differences have long been cited, but another factor also is at work: chronic depreciation of the currencies of low-wage countries as a result of the capital transfers they make in a vain attempt to service their foreign debts. In the end these debts will prove unpayable as they mount up at interest beyond the economic means to pay. The austerity programs used by the IMF and other creditor institutions are defended by models that conceal this mathematical inevitability. By depriving debtor economies of capital, educational programs and other basic infrastructure, austerity makes it harder for indebted countries to catch up. Matters are aggravated further by privatization programs that serve in effect as voluntary and self-imposed forfeitures of public assets to foreign and domestic creditors.

Creating a statistical profile of financial relationships is impaired by the fact that when wealthy individuals operate out of offshore banking centers, they appear nominally as "foreigners" in their own countries. Yet economists have constructed models in which such offshore havens, foreign debt, land values, and the composition of savings and debt appear 
as statistical black holes. Such omissions help these models serve as fairy tales to rationalize today's untenable status quo. Everyone is depicted as ending up in a stable and even equitable equilibrium.

A striking analogy of the impossibility of the world's financial savings continuing to grow at compound interest ad infinitum is pointed out by Edward $\mathrm{O}$. Wilson, in Consilience (New York: 1998:313), citing "the arithmetical riddle of the lily pond. A lily pod is placed in a pond. Each day thereafter the pod and then all its descendants double. On the thirtieth day the pond is covered completely by lily pods, which can grow no more." He then asks, "On which day was the pond half full and half empty? The twenty-ninth day."

By the time people feel obliged to argue over whether the economic glass if half empty or half full, we are on the brink of the Last Days. To financial optimists, it may be pointed out that growth in the economy's savings is simultaneously growth its debt overhead. As debts grow, less and less saving is recycled into tangible direct investment. This may be good news for stock market and real estate speculators as savings are used to inflate the stock market and real estate bubble. But in the end the economy shrinks precisely because this "faux wealth" serves as a distraction, drawing savings away from direct investment in tangible capital formation.

What is lacking in the models preferred by vested interests is the use of mathematics to project the point at which trends intersect. At these crisis points economic forces do not have an inherently economic "solution," for the response must be political, by forcing a policy conclusion to be made.

A relevant mathematical economics would include an analysis of how wealth is turned into political power by campaign contributions, ownership of the popular press and media, and the subsidy of education and culture. These public relations for the vested interests promote "solutions" to crises that increasingly favor these interests as the economy polarizes. The analysis of such phenomena is dismissed by general equilibrium theorizing that assumes a constant and unchanging political environment. Changes in laws are deemed to be exogenous to the subject matter of economics proper. The word "exogenous" is heard so often these days (along with "externalities") that one wonders just what is left in economics proper. At issue for a more relevant empirical economics are the dynamics of social history, political institutions and the environment, not just the mechanics of supply and demand.

Governments tend to become the debtors of last resort. The culmination of this process is found in modern financial bailouts of private-sector ("socializing the losses" to savers). So we are brought back to Adam Smith's maxim that no government has ever repaid its debts. This is why nobody's savings have mounted up to become the equivalent of a solid sphere of gold extending from the sun out beyond the orbit of Saturn. The 12th-century accumulation of wealth of the Knights Templar was seized by Philip the Fair, who dissipated it in warfare. The wealth of the large Italian banking families subsequently was lost in loans to Britain's kings, who dissipated the proceeds in waging their perpetual wars with France. Most early debts were wiped out by wars, and by their inflationary aftermath in more recent times. Other fortunes were lost through confiscation, and bad judgment such as often is found with risky foreign investment. Some fortunes were dissipated by one's heirs or turned into land acquisition and other prestige asset ownership.

The relevant point for the social historian is that financial fortunes cannot continue to accumulate in the aggregate, precisely because the mathematics of compound interest are 
economically untenable. Throughout history it has become increasingly difficult to keep such fortunes viable. Money has been plowed back into increasingly risky new loans in ways that may impoverish and polarize the surrounding society to the extent that they find no counterpart in new tangible investment enhancing the economy's means to pay.

The moral of all this is that there are different kinds of mathematical economics. What the Cornell philosopher E. A. Burtt referred to the metaphysical foundation of modern physical science has become a politically tinged metaphysics in the hands of monetarists and neoclassical economists. Just how far their non-quantitative spirit diverges from the origins of economics is reflected in the closing words of David Hume's Enquiry Concerning Human Understanding:

When we run over libraries, persuaded of these principles, what havoc must we make? If we take in our hand any volume; of divinity or school metaphysics, for instance; let us ask, Does it contain any abstract reasoning concerning quantity or number? No. Does it contain any experimental reasoning concerning matter of fact and existence? No. Commit it then to the flames: for it can contain nothing but sophistry and illusion.

\section{Mathematizing the economy's monetary and financial dimension}

Not all trends proceed at the same rate. At some point certain major trends must intersect, and something must give. This is the definition of a crisis - literally a crossing or intersection of trends where the political structure must accommodate itself to promote one trend or the other.

The example with which most people are familiar was made famous by Malthus, who argued that population growth tended mathematically to grow in excess of the economy's ability to supply food. The result, he concluded, must be starvation, wars or other "natural checks," or else a voluntary limit to population growth. Since the late 1960s the Club of Rome has warned that modern resource-consuming trends are unsustainable in light of the world's more limited growth in the supply of fuels and minerals, fresh water and air.

What these warnings achieved was to bring to peoples' attention the fact that whereas most mathematical economics has focused on foreseeable, narrowly determined consequences, over time the indirect "external" economies of commercial behavior tend to be larger than these direct economies. But they also have tended to evade mathematical and statistical treatment. ${ }^{3}$

The limits-to-growth warnings proved to be premature a generation ago, but one cannot say the same thing for the growth of debts/savings at compound interest year after year. Any statistician plotting the growth of an economy's debt quickly finds that existing trends are not sustainable. The growth of debt has become the major cause of economic

\footnotetext{
${ }^{3}$ As early as 1849, Daniel Lee attempted to quantify the environmental depletion suffered by rawmaterials exporters in his agricultural supplement to the U.S. Patent Office report. This "external" effect of foreign trade became an essential component of E. Peshine Smith's 1853 Manual of Political Economy (see Hudson 1975 for a discussion). Carey's Law of Association postulated that economies grow more productive at the intensive margin as they become more dense. But free traders have ignored these broad consequences, and used rhetorical invective censorially to dismiss them as "externalities."
} 
downturns, austerity and financial polarization, creating financial crashes and, in severe cases, social crises.

Debt may be viewed as financial pollution, entailing major cleanup costs. Public policy is needed to cope with the incompatibility between the inability of consumers, businesses and governments to pay their stipulated debt service except by transferring an intolerable proportion of their assets to creditors. These transfers are done through bankruptcy proceedings, the liquidation of corporate or personal assets under distress conditions and (in the case of government debts) privatization selloffs.

The indicated solution is to limit the proliferation of debt by borrowing less, for instance, and to channel savings more into equities and tangible investment than into debtclaims on economic output. If present trends continue, it will be necessary to write off debts when they become too overgrown. This entails writing off the savings that have been invested in debt-securities - and this has now become the major political problem of our epoch. Yet monetarists - the very people who claim to specialize in financial science - see this crisis as an anomaly rather than a natural consequence of pursuing Chicago School policies. They urge economies to submit to financial austerity by sanctifying debts rather than saving themselves and their labor force at the expense of debt and savings trends.

An enormous volume of statistical research has been produced to analyze money and prices, and their links to interest rates and hence to the prices of bonds and other financial assets. When examining such research one should bear in mind that monetarism focuses on only part of the credit supply: bank deposits and "high-powered money" in the form of reserves invested in government debt. In reality the economy's entire range of securities and other assets is available to be monetized or, more literally, creditized. The potential credit supply consists of the volume of marketable securities and debts outstanding (which their holders can collateralize as the basis for yet more credit) plus equity in "real" assets, that is, the portion of tangible asset values to which debts have not yet been attached.

Most money and credit is spent on transactions in financial securities, not on "real" goods and services. Each day the equivalent of almost an entire year's national income passes through the New York Clearing House to buy stocks, bonds, mortgages and other bank loans. It thus is misleading to correlate the money supply only to transactions in current goods and services ("national product"). Such correlation analysis is not necessarily causal in any event. It is all too easy to mistake cause for effect. It therefore would be misleading to leave out of account the pricing of financial assets (bonds, stocks, and marketable debt securities such as mortgages, packaged consumer loans and so forth) and of the tangible assets (land and buildings, factories and equipment) on which this credit is spent. Nonetheless, these asset transactions seem to have disappeared from statistical sight as the focal point of monetarist analysis has shifted away from wealth and assets to consumer spending. For instance, despite the fact that the major asset for most families (at least in America and Britain) is the home in which they live, no adequate statistical time series for land and buildings is collected or published. In many cases one is obliged to estimate real estate values by looking at the growth of mortgage credit as a minimal proxy.

The very idea of what constitutes money remains in a state of confusion. To describe it simply as a set of counters neglects the fact that bank deposits and savings do not take the form of money as an abstract asset in itself, like gold or silver bullion. Rather, currency and bank money are debt/credit instruments. One person's saving usually finds its counterpart in 
other peoples' debts. If an individual or company deposits money in a bank or savings and loan association, a large portion of the deposit will be lent out as mortgage credit. Or, a saver may put money in a money market fund that channels its inflows into government bonds and corporate IOUs. The definition of "money" thus needs to be grounded in the overall superstructure of credit and debt.

An expanding superstructure of financial claims for payment grows and attaches itself to the economy's income and assets. These claims find their counterpart in liabilities on the opposite side of the financial system's balance sheet (e.g., the debts owed by the banks to their depositors, by insurance companies to their policy-holders, and so forth). They are securitized by the issue of bonds, mortgages and other IOUs. They represent the savings of people and the institutions through which people hold their savings, including pension fund contributions, Social Security, bank loan portfolios, insurance company reserves, and so forth. All these savings/debts must be paid out of future revenue.

Financial securities are not simply a mirror image of "real" economic activity, the "other" side of the balance sheet of assets and debts. They are a claim for payment that may be equal to, less than or greater than the economy's ability pay. When it comes to deciding what must give, the economy or its financial superstructure, the latter turns out to be more powerful - and hence, more "real" - than the economy's tangible flows of output and income. Entire economies are being crucified on the altar of debt and subjected to austerity and its foregone economic development. On this basis financial institutions have become the major economic planners of our epoch, usurping the former role of governments. Yet monetarists profess to oppose such centralized planning. What they evidently oppose is planning by elected officials with a broader set of social concerns than those of monetarist technocrats.

At the microeconomic financial level it seems wise to maximize one's return on equity by indulging in debt pyramiding. But for the economy as a whole this debt accumulates interest. Savings are lent out to finance this debt, as well as that of business and government. Wealthier economies tend to become the most highly indebted precisely because they have the most savings. Interest and amortization payments to savers tend to increase beyond the economy's overall ability to pay as debt service absorbs more and more personal disposable income and corporate cash flow. This constrains personal and business spending, creating the phenomenon of debt deflation. Yet no mathematical models depicting this process has been deemed acceptable by today's monetarist orthodoxy.

If there is any planning to be done with regard to the banking and financial system, the central issue of mathematical economics as applied to the financial sector should focus on how economies should cope with the tendency for debts to mount up until a crisis erupts? Monetarist models deny that any practical debt limit exists. Economies are supposed to "solve" their debt problem simply by succumbing to austerity, which is presented as the solution to the problem rather than a sign of having entered the financially moribund stage.

Perception of the debt-overhead problem is concealed by the characteristic feature of today's finance capitalism: an asset-price inflation of property markets, that is, rising land and stock market prices. This asset-price inflation goes hand in hand with debt deflation of the "real" goods-and-service producing economy. The failure to model this dichotomized economy is not the fault of mathematical economics as such, but reflects the constrained reasoning at the hands of the monetarist school that has monopolized economics departments in the world's universities. 
Monetarist models serve largely to distract popular attention from the extent to which more wealth is being generated more by the asset-price inflation - than by building new factories to employ more people. What has happened is that the classical distinction between productive and unproductive credit has been replaced by an ostensibly value-free theory claiming that money earned in one way is just as economically worth while as money earned in any other way. This is supposed to be the case regardless of its consequences for employment, national prosperity or other effects held to be extraneous to purely financial concerns.

"Hard" facts tend to be the preoccupation of technocratic economics, whose predictions focus on the short run, that is, on marginal changes rather than structural transformations. But economic truth involves a much broader evaluation of society and even culture, as economic theory itself may be viewed as an exercise in cultural history. To the extent that "free market" monetarist economics has now become the world's de facto form of global planning, it threatens to bring about a poorer and more unfree world. If its models and their euphemisms do not make it clear just why this is the case, the reason is a politically motivated blind spot. Monetarist planning subjects the world to austerity to pay debts to a creditor class absorbing a growing proportion of the world's wealth, leading to economic polarization.

It is a world succumbing to economic collapse, heating up financially, ecologically and geographically to a critical mass. It also is heating up militarily as local provinces seek to secede from governments that are being turned into collection agents for global lenders. (Yugoslavia is the most notorious recent example.)

Trying to sell today's road to financial serfdom is much like trying to sell cigarettes. Popular fears of coughing, lung cancer, and other adverse effects are countered by advertising promises that cigarettes actually freshen the breath and are associated with vigorous outdoor life as epitomized by the Marlboro Man. Scientists are hired to provide a confusing flood of statistical analysis to dispute claims about smoking being causally associated with ill health, pretending that it is all just a coincidence. Neither the personal victims of smoking nor the public health agencies that must defray many of their medical costs are able to pierce the veil of such professionalized confusion.

In a similar way economists have been mobilized to serve creditor interests. Many of these hired guns act as public relations lobbies for global financial interests, often by joining think tanks that serve as advertising agencies to promote these interests. Their assigned task is to depict austerity as laying a sound foundation for future growth rather than promoting a self-feeding collapse. As poverty intensifies, governments are urged to bail out the economy's savers at taxpayer expense, cutting back wages even while shifting the tax burden from property onto labor. When the promised prosperity fails to materialize, the austerity lobby argues that the problem is simply that monetarist policies have not been followed intensively enough to "work their magic." But like most magic, the purported "magic of the marketplace" is merely a trick performed by model-builders so deftly that most peoples' eyes cannot quite follow what is happening.

As Eric Reinert has asked, if mathematical economics as practiced by the monetarists should face a product liability suit, what would be the appropriate judgment? If today's Chicago School orthodoxy were to be tested by reality, it would flunk the test. Jobs have been downsized. Lives have been shortened and the quality of life has declined as 
Chicago graduates and their clones have monopolized the staffs of national Finance Ministries, Treasury departments, central banks and the leading international financial institutions, using their positions to censor alternative economic analysis.

The crisis created between the economy's growth in debt and its ability to pay should be the starting point of mathematical economics.

\section{Bibliography}

Henry Adams (1919), The Degradation of the Democratic Dogma (New York).

Burtt, E. A. (1932), Metaphysical Foundations of Modern Science (London, 2nd ed.)

Hudson, Michael (1975), Economics and Technology in 19th-Century American Thought: The Neglected American Economists (New York).

Jordy, William H. (1952), Henry Adams: Scientific Historian (New Haven).

Marx, Capital, Vol. I (London, 1887)

Meier, Gerald (1968), The International Economics of Development; theory and policy (New York).

Mill, John Stuart (1844), Essays on Some Unsettled Questions in Political Economy (London).

Myrdal, Gunnar (1956), "How Scientific are the Social Sciences?" see An International Economy: Problems and Prospects (New York).

Nicholson, J. Shield (1893), Principles of Political Economy (London).

Samuelson, Paul (1939), "The Gains from International Trade," Canadian Journal of Economics and Political Science 5:195:205), repr. Papers, II:781-971.

Samuelson, Paul (1949), "International Factor-Price Equilibrium Once Again," Economic Journal 59:181197 (repr. Papers, II:869-85).

Samuelson, Paul (1966), The Collected Scientific Papers of Paul A. Samuelson, ed. Joseph E. Stiglitz, Vol. II. (Cambridge, Mass.)

Vickery, William (1964), Microeconomics (New York).

Wilson, Edward O. (1998), Consilience (New York).

SUGGESTED CITATION:

Michael Hudson, "The use and abuse of mathematical economics", real-world economics review, issue no. 55, 17

December 2010, pp. 2-22, http://www.paecon.net/PAEReview/issue55/Hudson255.pdf

You may post and read comments on this paper at http://rwer.wordpress.com/2010/12/17/rwer-issue-55-michael-hudson-2/ 